\title{
Therapeutic Benefits of Methanolic Extract of Moringa Oleifera Leaf Extract in Dyslipidemia: Observational Comparative Follow up Study
}

Mrinal Kunj ${ }^{1}$, Uma Shanker Prasad Keshri ${ }^{2}$, Chandramani Kumar ${ }^{3}$, Rishabh Rana ${ }^{4}$, Siddharth Kapoor ${ }^{5}$, Dr. Anshu Kumar ${ }^{6 *}$

${ }^{1}$ DM Cardiology Resident, SCBMCH, Cuttack, Odisha, India

${ }^{2}$ Professor, Department of Pharmacology, RIMS, Ranchi, Jharkhand, India

${ }^{3}$ Assistant Professor, Department of Preventive \& Social Medicine, HMCH, Hazaribag, Jharkhand, India

${ }^{4}$ Assistant Professor, Department of Preventive \& Social Medicine, PMCH, Dhanbad, Jharkhand, India

${ }^{5}$ Senior Resident, Department of Medicine, RIMS, Ranchi, Jharkhand, India

${ }^{6}$ Ex-TUTOR Department of Pharmacology, HMCH, Hazaribag, Ex-Junior Resident (MD 2016-2019), RIMS, Ranchi, Jharkhand, India

*Corresponding author: Dr. Anshu Kumar

\section{Abstract}

Background and Aim: Hyperlipidemia is implicated in metabolic diseases like Diabetes mellitus, arteriosclerosis, Hypertension, Obesity, Stroke, Cancer etc. In recent past Methanolic Extract of Moringa oleifera leaves (MEMOL) has gained enormous attention owing to its ameliorative effect in various metabolic diseases. MEMOL has profound hypolipidemic activity due to the presence of Chlorogenic acids (CGA) that causes elimination of lipids [1]. Materials \& Methods: Total 90 patients were a part of this study out of which 30 were healthy individuals who were in Control group A. Group B included 30 patients taking Moringa oleifera 500mg BD, Group C included 30 patients taking Moringa $(500 \mathrm{mgBD})+$ Atorvastatin $(10 \mathrm{mgOD})$. Lipid profile of all of the patients were followed up at the end of 12 weeks and 24 weeks. Lipid profile (Lipid Panel) included LDL, TSC, VLDL \& HDL. Results \& Conclusion: There was statistical significance in reduction of VLDL at the end of 12 and 24weeks in Group B which might be explained by MEMOL containing CGA. TSC, LDL, HDL changes at the end of 24weeks was statistically significant in Group C. CGA is the bioactive component present in MEMOL which inhibits the action of HMG Co-A reductase and also reduces expression of SREBP1c $[2,3]$ which attributes to its antihyperlipidemic action.

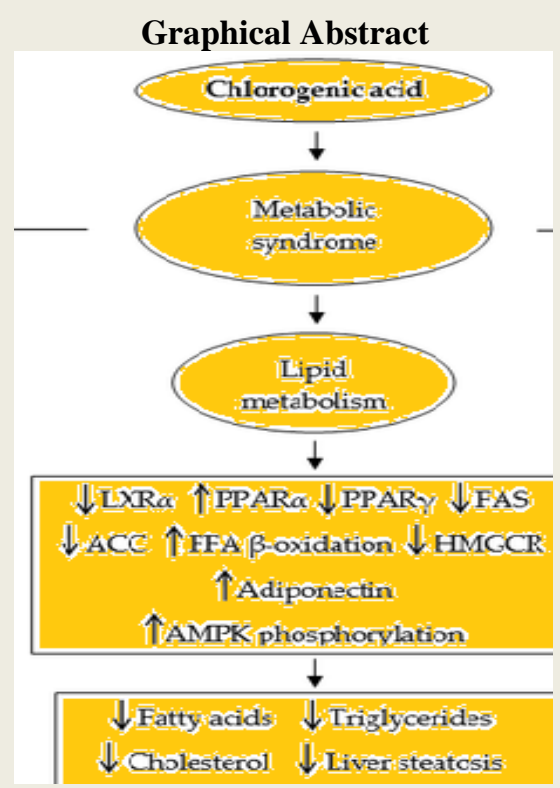

Keywords: Moringa oleifera, Methanolic extract, phytoconstituent, Chlorogenic acid, HMGCo-A reductase activity, Dyslipidemia.

Copyright (C) 2020 The Author(s): This is an open-access article distributed under the terms of the Creative Commons Attribution 4.0 International License (CC BY-NC 4.0) which permits unrestricted use, distribution, and reproduction in any medium for non-commercial use provided the original author and source are credited. 


\section{INTRODUCTION}

Dyslipidemia is a modifiable risk factor that needs to be identified early to institute cardiovascular preventive management. Typical findings are elevation of total cholesterol, VLDL cholesterol, triglycerides, exaggerated postprandial lipidemia, lowering of HDL cholesterol and a predominance of small, dense LDL-C particles [4].

Type 2DM is associated with a marked increase in risk of Cardiovascular disease (CVD). After an acute coronary event diabetic subjects tend to develop Congestive heart failure and have a higher mortality rate than non-diabetic individuals [5].

Dyslipidemia is also associated with metabolic syndrome. This association may be the mechanism by which T2DM tends to cause Cardiovascular diseases. The presence of type 2DM with any other risk factor is sufficient to consider an initiation of lipid lowering therapy as a primary prophylaxis for CAD (Coronary artery disease) which includes both lifestyle modifications and statin therapy [6].

Both pharmacological and non-pharmacological agents have been employed as lipid lowering agents. Atorvastatin (HMGCo-A Reductase inhibitors) are the prototype amongst Statins as pharmacological agents [7].

Herbal plants that have been of remarkable importance includes Reserpine (Rauwolfia serpentina), Chinese herb manhung, Ephedrine from Ephedra vulgaris, Digitalis from Digitalis purpurea, Quinine from Cinchona bark and most importantly Metformin from Galega officinalis [8].

Around $25 \%$ of the synthesized drugs are manufactured from medicinal plants [17]. Plethora of research has been done to establish beneficial effects of plant products in metabolic disorders. Medicinal herbs, a rich mine for bioactive chemicals are markedly free of undesirable side effects and possess powerful pharmacological actions. The huge diversity in phytoconstituents contributes to their numerous pharmacological actions and uses [9].

Moringa oleifera sp. has attracted attention in recent past owing to its therapeutic potential and versatility. Moringaceae is the most widely distributed and naturalized species known to human [10]. Moringa oleifera was well known to the Siddha healers in ancient era. Almost all of its parts are consummable which includes fruits (sahjan), flowers, leaves, stem and roots. The fruit is widely used as an edible delicacy in India. Most of the drug preparations of Moringa employ leaf extract in therapeutics commonly called as MEMOL [11].
The leaves are most therapeutically active that contains natural antioxidants, Carotenoids, mustard oil glycosides, saponins, tannins, phenolic compounds, oxalates and $\beta$-sitosterol [12]. Glucosinolates (Glucomoringin) and Chlorogenic acids present in the leaves are the active constituent responsible for antihyperlipidemic and antihyperglycemic effect [13]. $\beta$-sitosterol possesses bioactive material which is documented to lower lipid levels. MEMOL also contains phenolic compounds that are hypolipidemic in action. The fresh leaf juice was found to curb the growth of microbes, Staph. Aureus, Pseudomonas aeruginosa and also has blood pressure normalizing property [14].

\section{MATERIALS AND METHODS}

This observational comparative follow up study was conducted in the Department of Pharmacology \& Therapeutics, Rajendra Institute of Medical Sciences (RIMS), Ranchi amongst the patients attending Medicine outdoor department.

\section{Ethical Consideration}

The approval was taken prior from the 'Institutional Ethics Committee' of Rajendra Institute of Medical Sciences (RIMS), Ranchi. Case Record form and Informed Consent form were framed prior to including patients in the study. A written informed consent was obtained his/her signature. Left thumb impression was taken from illiterate patients. All these above procedures were done in the presence of an appropriate and unbiased witness.

\section{Study Design}

Study.

An Observational Comparative Follow up

\section{Study Duration}

The study was conducted from June 2016 to July 2018. Every participant was followed up for 24 weeks in totality following their selection and screening (1-2weeks).

\section{Inclusion Criteria}

Patients whose lipid levels were in the range LDL(160-189), Total serum cholesterol TSC (200-239), HDL $(<40) \mathrm{mg} / \mathrm{dl}$ of either sex taking Moringa oleifera capsules with or without combination with other drugs namely Atorvastatin(10mg OD) were included in this study.

\section{Exclusion Criteria}

Pregnant, lactating women, patients with Cardiovascular diseases, hepatobiliary diseases, renovascular diseases, history of stroke, Transient ischaemic attack(TIA), patients taking other hypolipidemic drugs (Ezetimibe, Fibrates) and patients who got MI in past 6 mnths were excluded from the study. 


\section{STUDY METHODOLOGY}

Patients were screened for Dyslipidemia for about 1-2weeks and amongst them who qualified were comprehended about the study in a simple non- technical language that was easy to understand by the patient. Participant's consent was taken in writing (Literate) and Left thumb impression for illiterate using the Informed consent form in the presence of an appropriate unbiased witness. The participants were randomly allocated their respective groups accordingly as per OPD visit and followed up. Every participant was followed up for 6 months commencing from their screening and group allocation. They were counselled to visit the center at 12 weeks and at the end of 24 weeks.

The GROUP allocation was as follows:

Group A: Individuals who are not taking any antihyperlipidemic drugs.

Group B: Patients who were prescribed Moringa oleifera capsules (500mg BD).

Group C: Patients who were prescribed Moringa capsules 500mg BD+ Atorvastatin 10mg OD.

Detailed history and thorough clinical examination was done for all the participants. The participant's biochemical parameters like LDL, VLDL, TSC \& HDL in mg/dl were evaluated at the end of 12 and 24weeks. The blood sample of every participant was taken and sent to the laboratory for further investigations. Case record forms were maintained and filled in all subsequent visits.

\section{Diagnostic Evaluation}

Repeated measurements of LDL, VLDL, TSC

\& HDL in $\mathrm{mg} / \mathrm{dl}$ were taken and accompanied by detailed family history, clinical history, physical examination and laboratory investigations.

\section{Clinical History}

Thorough family history, chief complaints, history of present illness, past history, personal history and treatment history was taken and recorded. Menstrual history was taken from females.

\section{Follow Up Schedule}

Follow ups were scheduled at 12 weeks and 24 weeks, commencing from the screening procedure and allocation of groups.

\section{Assessment of Any Untoward Effects}

During the screening visits every participant undergoes a physical examination and medical history. Any adverse event or untoward effects were collected and recorded in the upcoming follow up visits.

\section{STATISTICAL ANALYSIS}

All the participants at the end of 24weeks were evaluated by summing up all the data available. The data were expressed as Mean and Standard deviation (SD). P value $<.05$ was considered as statistically significant. Data were entered in Microsoft excel 2010 and Data evaluated in IBM SPSS 20.0 version. For Intragroup comparisons Independent sample t test was used. For Intergroup comparisons Levene's test was used.

\section{RESULTS}

Data was expressed as Mean, Standard deviation and as \% wherever required. ' $p$ value' $<0.05$ was considered as statistically significant. No. of patients in Group A were 26, Group B were 29 and Group C were 27.

\section{OBSERVATIONS}

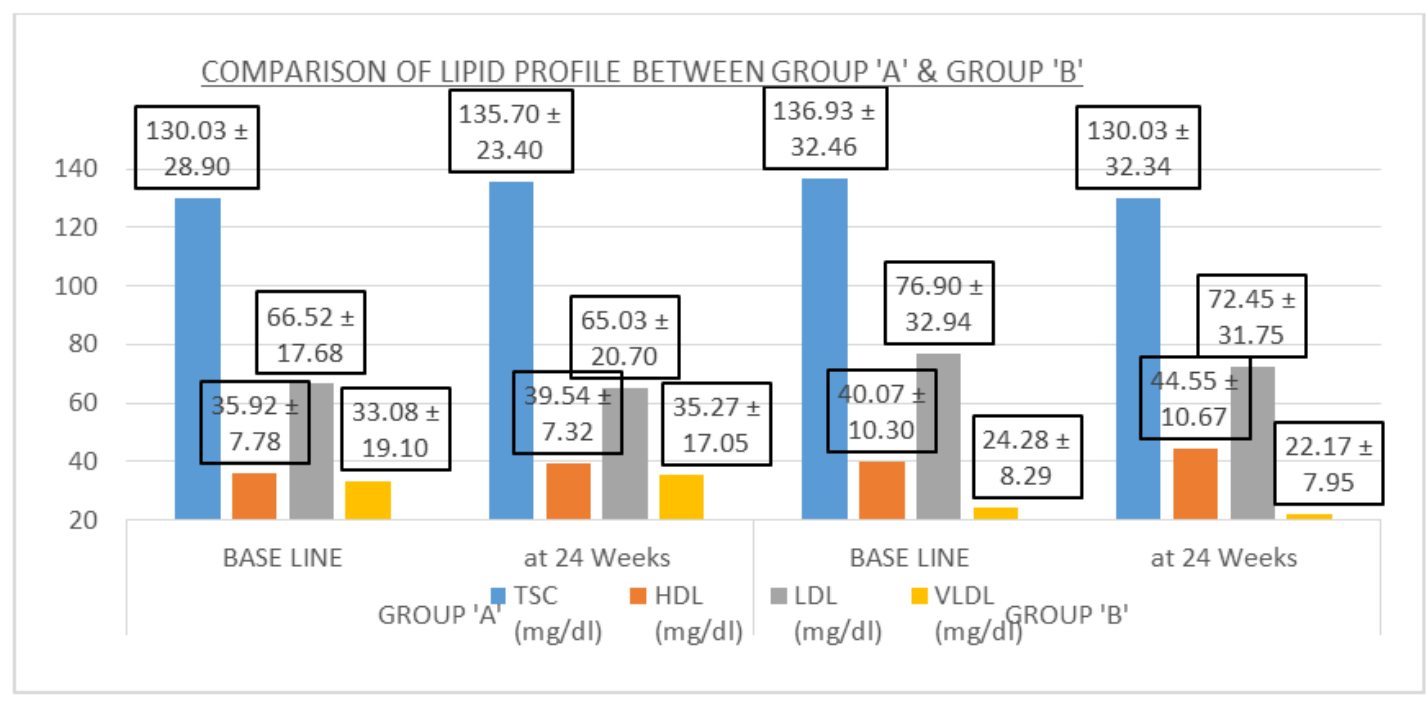

Graph-1 
TABLE 1

\begin{tabular}{|c|c|c|c|c|c|c|c|c|}
\hline \multicolumn{9}{|c|}{ MEAN HDL VALUES (mg/dl) OF GROUP 'A', 'B', 'C' \& p-VALUE AT BASE LINE, 12 \& 24 WEEKS } \\
\hline \multirow[t]{2}{*}{ GROUPS } & \multirow[t]{2}{*}{$\begin{array}{l}\text { HDL }(\mathrm{mg} / \mathrm{dl}) \\
\text { BL } \\
+ \text { SD }\end{array}$} & \multirow{2}{*}{$\begin{array}{l}\text { HDL }(\mathrm{mg} / \mathrm{dl}) \\
\text { at } 12 \text { Weeks } \\
\pm \text { SD }\end{array}$} & \multirow[t]{2}{*}{ p-Value } & \multicolumn{2}{|c|}{\begin{tabular}{|l|} 
HDL $(\mathrm{mg} / \mathrm{dl})$ \\
BL \\
\end{tabular}} & \multirow{2}{*}{\multicolumn{2}{|c|}{$\begin{array}{l}\text { HDL }(\mathrm{mg} / \mathrm{dl}) \\
\text { at } 24 \text { Weeks } \\
\pm \text { SD }\end{array}$}} & \multirow[t]{2}{*}{ p- Value } \\
\hline & & & & \pm SD & & & & \\
\hline $\begin{array}{l}\text { CONTROL } \\
\text { (Group-A) }\end{array}$ & $\begin{array}{l}35.92 \\
7.78\end{array}$ & $\begin{array}{l}39.46 \\
7.14\end{array}$ & 0.138 & $\begin{array}{l}35.92 \\
7.78\end{array}$ & \pm & $\begin{array}{l}39.54 \\
7.32\end{array}$ & \pm & 0.05 \\
\hline $\begin{array}{l}\text { MORINGA } \\
\text { (Group-B) }\end{array}$ & $\begin{array}{l}40.07 \\
10.30\end{array}$ & $\begin{array}{l}42.72 \\
8.73\end{array}$ & 0.641 & $\begin{array}{l}40.07 \\
10.30\end{array}$ & \pm & $\begin{array}{l}44.55 \\
10.67\end{array}$ & \pm & 0.483 \\
\hline $\begin{array}{l}\text { MORINGA + ATORVASTATIN } \\
\text { (Group-C) }\end{array}$ & $\begin{array}{l}41.93 \\
6.52\end{array}$ & $\begin{array}{l}43.28 \\
5.54\end{array}$ & 0.05 & $\begin{array}{l}41.93 \\
6.52\end{array}$ & & $\begin{array}{l}46.59 \\
4.90\end{array}$ & \pm & 0.04 \\
\hline
\end{tabular}

TABLE 2

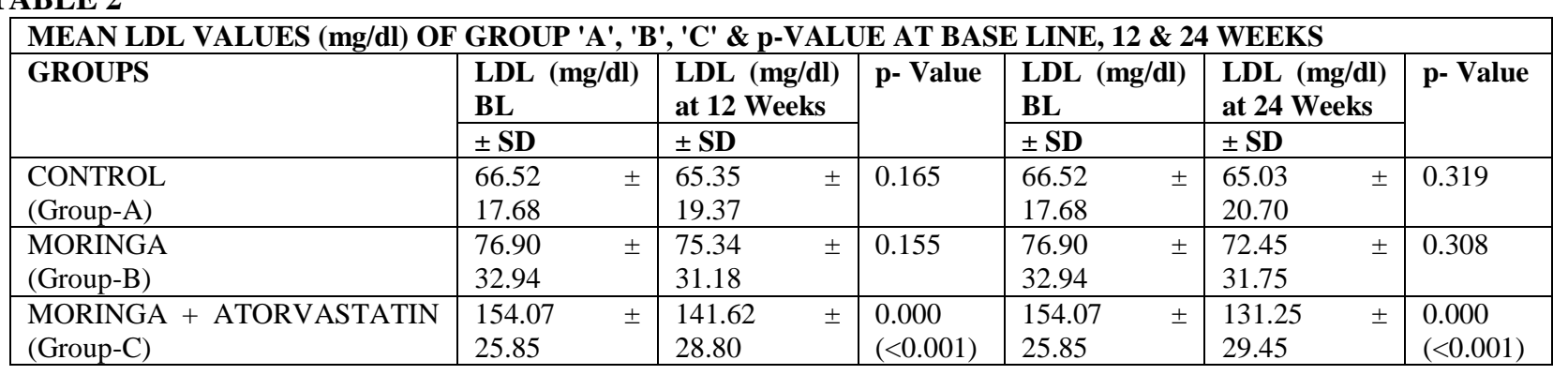

TABLE 3

\begin{tabular}{|c|c|c|c|c|c|c|}
\hline \multicolumn{7}{|c|}{ MEAN TSC VALUES (mg/dl) OF GROUP 'A', 'B', 'C' \& p-VALUE AT BASE LINE, 12 \& 24 WEEKS } \\
\hline \multirow[t]{2}{*}{ GROUPS } & $\begin{array}{l}\text { TSC }(\mathbf{m g} / \mathbf{d l}) \\
\text { BL }\end{array}$ & $\begin{array}{l}\text { TSC }(\mathrm{mg} / \mathrm{dl}) \\
\text { at } 12 \text { Weeks }\end{array}$ & \multirow[t]{2}{*}{ p- Value } & \begin{tabular}{|l|} 
TSC $(\mathrm{mg} / \mathrm{dl})$ \\
BL
\end{tabular} & \multirow{2}{*}{$\begin{array}{l}\text { TSC (mg/dl) } \\
\text { at } 24 \text { Weeks } \\
+ \text { SD }\end{array}$} & \multirow[t]{2}{*}{ p- Value } \\
\hline & \pm SD & \pm SD & & \pm SD & & \\
\hline $\begin{array}{l}\text { CONTROL } \\
\text { (Group-A) }\end{array}$ & $\begin{array}{l}130.03 \\
28.90\end{array}$ & $\begin{array}{l}132.69 \\
25.00\end{array}$ & 0.832 & $\begin{array}{l}130.03 \\
28.90\end{array}$ & $\begin{array}{ll}135.70 \quad \pm \\
23.40\end{array}$ & 0.212 \\
\hline $\begin{array}{l}\text { MORINGA } \\
\text { (Group-B) }\end{array}$ & $\begin{array}{l}136.93 \\
32.46\end{array}$ & $\begin{array}{l}131.00 \\
32.76\end{array}$ & 0.063 & $\begin{array}{l}136.93 \\
32.46\end{array}$ & $\begin{array}{l}130.03 \\
32.34\end{array}$ & 0.068 \\
\hline $\begin{array}{l}\text { MORINGA + ATORVASTATIN } \\
\text { (Group-C) }\end{array}$ & $\begin{array}{l}230.06 \\
24.70\end{array}$ & $\begin{array}{l}214.41 \\
24.78\end{array}$ & $\begin{array}{l}0.000 \\
(<0.001)\end{array}$ & $\begin{array}{l}230.06 \\
24.70\end{array}$ & $\begin{array}{l}199.55 \\
22.35\end{array}$ & $\begin{array}{l}0.000 \\
(<0.001)\end{array}$ \\
\hline
\end{tabular}

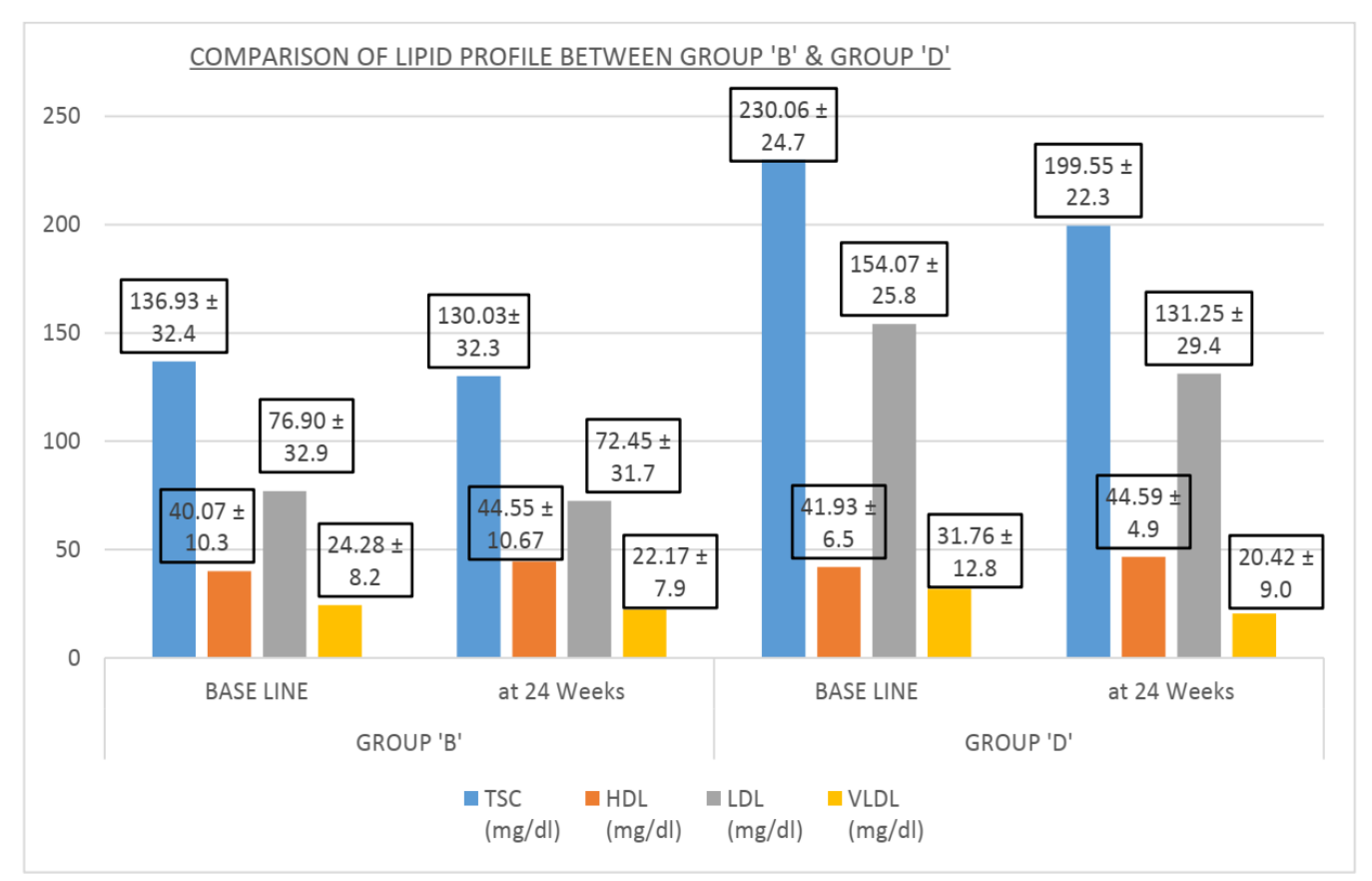

Graph-2 
TABLE 4

\begin{tabular}{|c|c|c|c|c|c|c|}
\hline \multicolumn{7}{|c|}{ MEAN VLDL VALUES (mg/dl) OF GROUP 'A', 'B', 'C' \& p-VALUE AT BASE LINE, 12 \& 24 WEEKS } \\
\hline \multirow[t]{2}{*}{ GROUPS } & $\begin{array}{c}\text { VLDL (mg/dl) } \\
\text { BL }\end{array}$ & $\begin{array}{l}\text { VLDL }(\mathrm{mg} / \mathrm{dl}) \\
\text { at } 12 \text { Weeks }\end{array}$ & \multirow[t]{2}{*}{ p- Value } & $\begin{array}{c}\text { VLDL (mg/dl) } \\
\text { BL }\end{array}$ & $\begin{array}{l}\text { VLDL }(\mathrm{mg} / \mathrm{dl}) \\
\text { at } 24 \text { Weeks }\end{array}$ & \multirow[t]{2}{*}{ p- Value } \\
\hline & $\pm \mathrm{SD}$ & $\pm \mathrm{SD}$ & & $\pm \mathrm{SD}$ & $\pm \mathrm{SD}$ & \\
\hline $\begin{array}{l}\text { CONTROL } \\
\text { (Group-A) }\end{array}$ & $\begin{array}{c}33.08 \pm \\
19.10\end{array}$ & $\begin{array}{c}31.27 \pm \\
18.38\end{array}$ & 0.523 & $\begin{array}{c}33.08 \pm \\
19.10\end{array}$ & $\begin{array}{c}35.27 \pm \\
17.05\end{array}$ & 0.436 \\
\hline $\begin{array}{c}\text { MORINGA } \\
(\text { Group-B) } \\
\end{array}$ & $\begin{array}{c}24.28 \pm \\
8.29\end{array}$ & $\begin{array}{c}23.41 \pm \\
9.01\end{array}$ & 0.05 & $\begin{array}{c}24.28 \pm \\
8.29\end{array}$ & $\begin{array}{c}22.17 \pm \\
7.95\end{array}$ & 0.03 \\
\hline $\begin{array}{c}\text { MORINGA + ATORVASTATIN } \\
(\text { Group-C) }\end{array}$ & $\begin{array}{l}31.76 \pm \\
12.84\end{array}$ & $\begin{array}{l}25.07 \pm \\
10.52\end{array}$ & 0.04 & $\begin{array}{c}31.76 \pm \\
12.84\end{array}$ & $\begin{array}{c}20.42 \pm \\
9.01\end{array}$ & $\begin{array}{c}0.000 \\
(<0.001)\end{array}$ \\
\hline
\end{tabular}

\section{DISCUSSION \\ EFFECTS OF MORINGA OLEIFERA (GROUP B) ON LIPID PROFILE}

TSC mean value reduced at the end 12 and 24 weeks for both of which $\mathrm{p}$ value was statistically insignificant. HDL mean value raised at 12 and 24 weeks (10\%), but ( $\mathrm{p}$ value $.641 \& .483$ respectively) was statistically insignificant. LDL reduced at the end of 12 and 24 weeks $(5.7 \%)$ but the changes were statistically insignificant ( $\mathrm{p}$ value 155 and .308 ). VLDL mean values reduced at the end of 12 and 24 weeks which ( $p$ value was .05 and .001$)$ was statistically significant. The reduction in mean VLDL at the end of $12 \& 24$ weeks might be explained by the presence of Chlorogenic acids in MO leaves extract that act in a similar way as statins do. Moringa leaf extract also contains $\beta$ sitosterol and phenolic compounds that might cause hypolipidemia. Phenolic acids derived from Moringa oleifera contains Chlorogenic acid (CGA). Chlorogenic acid reduces plasma total serum cholesterol(TSC), triglycerides in obese zucker rats and HFD mice [3].

In a preclinical study done by Carrie Waterman et al on mice in Department of plant biology, USA demonstrated that Moringa leaf extract regulates lipogenic proteins SREBP1(Sterol regulatory element binding protein), FAS (First apoptotic signal) thereby mediating lipolysis hence controls hyperlipidemia. This study clearly demonstrates that Moringa containing CGA might have beneficial effects in preventing and treating obesity. The antihyperlipidemic effects of $\mathrm{M}$. oleifera leaves were evaluated in rats fed with a high fat diet (HFD) by Ghasi et al., [12]. Wistar rats were fed with HFD containing $(16 \% \mathrm{w} / \mathrm{w}$ fat $)$ for 30 days. Aqueous extract of M. oleifera leaves at a daily dose of $1 \mathrm{~g} / \mathrm{kg}$ body weight (b w) was given and compared with untreated rats. In untreated rats, the diet caused $30 \%$ increase in plasma total cholesterol whereas in treated rats, the increase was reduced to $14 \%$.

\section{Effects of Moringa Oleifera+Atorvastatin (10mg) on Lipid Profile (GROUP C)}

In this study, the Mean TSC reduced at $12 \&$ 24weeks which was (p value was .000 and .000 respectively) statistically significant. Mean LDL reduced at $12 \& 24$ weeks (.000 and .000$)$ both of which were statistically significant. Mean VLDL values reduced at $12 \& 24$ weeks, for which p values were statistically significant (.04 \&.000 respectively). The significant reduction in lipid parameters might be explained due to the HMG Co-A reductase activity of Atorvastatin. In a study done by Roxana Sadeghi et al., in Nov'2014 obtained lipid lowering effects of Atorvastatin after 3 months in ischemic cerebrovascular accident patients [15]. Isothiocyanates rich MEMOL reduces weight gain and hepatic adiposity while increasing lipolysis [16].

\section{CONCLUSION}

Moringa oleifera has been used to manage both Diabetes and dyslipidemia as a home remedy however due to paucity of extensive clinical studies its efficacy is not well established. This study was carried out to corroborate the benefits of MEMOL in dyslipidemia. Results closely demonstrate that MEMOL may improve Dyslipidemia in the face of continued use by attenuating HMGCo-A reductase activity. More robust clinical studies are needed to substantiate these claimed myriads of benefits of Moringa oleifera (MEMOL). These studies may pave ways to the development of new novel compounds as drugs like MEMOL.

This observational study was just an approach to unravel the hypolipidemic effects and safety of this herbal preparation.

Disclosure of Conflicts of Interests: All the authors have nothing to disclose as far as conflicts of interests are concerned.

\section{Authors Contributions}

Dr. Anshu Kumar, Dr. Mrinal Kunj \& Dr. Uma Shanker Keshri designed the study. Dr. Anshu Kumar wrote the complete manuscript and was in charge of major practical work and interpretation of data. Dr. Mrinal kunj had pivotal role in the technical work and segregation of patients in respective groups. Dr. Chandramani and Dr. Rishabh Rana were involved in the statistical analysis of the data. Dr. Siddharth Kapoor was involved in maintaining Case record forms, follow ups of all participants in subsequent visits and procurement of Moringa oleifera capsules. 


\section{REFERENCES}

1. Atawodi SE, Atawodi JC, Idakwo GA, Pfundstein B, Haubner R, Wurtele G, Bartsch H, Owen RW. Evaluation of the polyphenol content and antioxidant properties of methanol extracts of the leaves, stem, and root barks of Moringa oleifera Lam. Journal of Medicinal Food. 2010 Jun 1;13(3):710-6.

2. Shi H, Dong L, Dang X, Liu Y, Jiang J, Wang Y, Lu X, Guo X. Effect of chlorogenic acid on LPS-induced proinflammatory signaling in hepatic stellate cells. Inflammation Research. 2013 Jun 1;62(6):581-7.

3. Cho AS, Jeon SM, Kim MJ, Yeo J, Seo KI, Choi MS, Lee MK. Chlorogenic acid exhibits anti-obesity property and improves lipid metabolism in high-fat diet-induced-obese mice. Food and chemical toxicology. 2010 Mar 1;48(3):937-43.

4. American Diabetes Association. Standards of Medical Care in Diabetes. Diabetes Care 2007; 30:4-41.

5. Mooradian AD. Dyslipidemia in type 2 diabetes mellitus. Nat Clin Pract Endocrin Metab. 2009; $5: 150-159$

6. Mitra A, Bhattacharya D, Roy S. Dietary influence on TYPE 2 Diabetes (NIDDM). Journal of Human Ecology. 2007 Feb 1;21(2):139-47.

7. Jurukovska-Nospal M, Arsova V, Levchanska J, Sidovska-Ivanovska B. Effects of statins (atorvastatin) on serum lipoprotein levels in patients with primary hyperlipidemia and coronary heart disease. Prilozi. 2007; 28(2):137-48.

8. Prakash D, Gupta C. Glucosinolates: The phytochemicals of nutraceutical importance. Journal of Complementary and Integrative Medicine. 2012 Jul 2;9(1).

9. Rout SP, Chowdary KA, Kar DM, Das L. Plants as source of novel anti-diabetic drug: present scenario and future perspectives. Current Trends in Biotechnology and Pharmacy. 2009;3(1):37-55.
10. Ara N, Rashid M, Amran MS. Comparison of Moringa oleifera leaves extract with atenolol on serum triglyceride, serum cholesterol, blood glucose, heart weight, body weight in adrenaline induced rats. Saudi J Biol Sci. 2008 Dec $1 ; 15(2): 253-58$.

11. Anwar F, Bhanger MI. Analytical characterization of Moringa oleifera seed oilgrown in temperate regions of Pakistan. Journal of Agricultural and Food Chemistry. 2003; 51: 6558- 6563.

12. Ghasi S, Nwobodo E, Faizi S, Siddiqui BS, Saleem $\mathrm{R}$, Saddiqui S, Aftab K. Isolation and structure elucidation of new nitrile and mustard oil glycosides from Moringa oleifera and their effect on blood pressure. Journal of National Production. 1994; 57: 1256-1261.

13. Faizi S, Siddiqui BS, Saleem R, Siddiqui S, Aftab $\mathrm{K}$, Gilani $\mathrm{AH}$. Isolation and structure elucidation of new nitrile and mustard oil glycosides from Moringa oleifera and their effect on blood pressure. J Nat Prod.1994; 57: 1256-1261.

14. Wang TY, Newby LK, Chen AY, Mulgund J, Roe MT., Sonel AF, Bhatt DL, DeLong ER, Ohman EM, Gibler WB, Peterson ED. Hypercholesterolemia paradox in relation to mortality in acute coronary syndrome. Clinical Cardiology. 2009; 32(9): E22-8.

15. Sadeghi R, Asadpour-Piranfar M, Asadollahi M, Taherkhani M, Baseri F. The effects of different doses of atorvastatin on serum lipid profile, glycemic control, and liver enzymes in patients with ischemic cerebrovascular accident. ARYA atherosclerosis. 2014 Nov;10(6):298.

16. Skau CT, Waterman CM. Specification of architecture and function of actin structures by actin nucleation factors. Annual review of biophysics. 2015 Jun 22;44:285-310.

17. Pan Y, Xia J, Gao L, Shen C, Zeng C. Calculation of Rayleigh-wave phase velocities due to models with a high-velocity surface layer. Journal of Applied Geophysics. 2013 Sep 1;96:1-6. 